\title{
Entrepreneurial Potential Influence to Intention of Students Based on Gender
}

DOI: https://doi.org/10.47175/rissj.v2i4.284

\section{| Lena Ria Bela ${ }^{1, *} \mid$ Asri Laksmi Riani ${ }^{2}$ Mintasih Indriayu ${ }^{3}$}

\author{
${ }^{1,2,3}$ Faculty of Economics \\ Education, Sebelas Maret \\ University, Surakarta, \\ Indonesia
}

*lenariabela@gmail.com

\begin{abstract}
Gender inequality is one of the keys to entrepreneurial activity in general and especially for entrepreneurial intentions in encouraging to set up new businesses. Entrepreneurial intention grows from the presence of entrepreneurial potential, so an entrepreneur needs to have an entrepreneurial intention in itself. It is interesting to study whether the entrepreneurial potential of men is stronger than women so that men have more intentions to set up their new businesses than women?. The study method used is hierarchical multiple regression analysis with a research population of 402 students and the sample to be used is 200 students. Proportional stratified random sampling is a type of probability sampling technique used in this study. Test the validity and reliability using the product-moment correlation formula from Pearson and the formula for calculating Cronbach alpha ( $\alpha$ ). The results of the analysis show Entrepreneurial potential significantly affects student intention, but gender does not significantly moderate the relationship.

KEYWORDS

entrepreneurial intention; gender; intention; entrepreneurial potential
\end{abstract}

\section{INTRODUCTION}

Generally, gender inequality has an important role in entrepreneurial activities, because someone who studies the dynamics of gender inequality in entrepreneurship, indirectly gender inequality becomes a major thing as well (Bastian et al., 2019). Females have much lower entrepreneurial participation than Male. Gender inequality in entrepreneurship causes constant and intense discussion in academics as well as in everyday life (Gupta et al., 2014). Gender has a significant influence on entrepreneurial intentions to open new businesses in the future, and being an entrepreneur is mostly done by males than females (Vodă \& Florea, 2019).

Entrepreneurial intention is needed by someone in starting the entrepreneurship procedure. Starting from the entrepreneurial intention possessed by a person will make him prefer a career as an entrepreneur, then will dare him to take calculated risks, start collecting the resources needed, and finally ready to establish a business (Abou et al., 2020). The entrepreneurial intention will provide an understanding of the antecedents in predicting entrepreneurial action (Mamman et al., 2019). The one's intention to have participated in the process of forming the emergence of activities that lead to establishing a business could be defined as an entrepreneurial intention (Syed et al., 2020). the belief if someone who consciously plans and builds new businesses in the future to achieve long-term goals is also called entrepreneurial intention (Thompson, 2009). There are various challenges that must be faced by every entrepreneur, from small things to big things (Tambunan, 2021). 
So, entrepreneurial intention can be identified as the desire and encouragement of psychological beliefs of one to take part in entrepreneurial activity. Entrepreneurial intention can be considered as the best predictor of the Theory of Planned Behavior and in general, every individual has a different intention and can be studied (Krueger \& Brazeal, 1994). Writes down three components in influencing one's intention to act, namely perceived behavioral control, subjective norms, and attitudes toward behavior. The entrepreneurial potential will generate intentions in a person (Elina et al., 2015).

Entrepreneurial potential variables are important to be taken into account by gender (Dilli $\&$ Westerhuis, 2018). The entrepreneurial potential is a complete series of processes including self-cognition and psychological perception, having entrepreneurial competence and entrepreneurial motivation, taking risks, and having self-confidence which all of these processes will encourage them to have intentions and carry out entrepreneurial activities (Santos et al., 2013). Entrepreneurial potential has defined as a unit or combination of human capital which includes entrepreneurial skills and knowledge, has capital, and has a network of cooperation in establishing a new business in a certain environment (Pauli \& Osowska, 2019). Gender differences can be analyzed through entrepreneurial potential which consists of the environment and entrepreneurial personality traits that can encourage someone to have the intention of running a business (Ward et al., 2019).

So, this study identifies entrepreneurial potential in one's cognition and psychology to build entrepreneurial intentions to run a business. Cognition and psychology lead to entrepreneurial skills and personality traits of a person. Personality traits can affect the intention to set up a business so it needs to be considered (Sargani et al., 2019). A person must have personality traits as important factors in influencing entrepreneurial intentions (Mubarik et al., 2020). Personality traits have four dimensions that can develop one's entrepreneurial intentions, namely entrepreneurial alertness, risk tolerance, locus of control, and need for achievement (Karabulut, 2016). Self-efficacy, locus of control, and need for achievement are three dimensions of personality traits (Kristiansen \& Indarti, 2004). Personality traits can be seen from the big five models and also Locus of control (both internal and external). Motivation tends to be an intrinsic component of personality traits, this motivation is related to achievement motivation (need for achievement) (Qian et al., 2020).

OECD individual entrepreneurial skills, business management, and technology are the three key skills needed by entrepreneurs. Strategic thinking skills, self-control and discipline, persistence, innovation, change and risk management, leadership, and network building are the things possessed by personal entrepreneurial skills (Hatthakijphong \& Ting, 2019). Behavior that includes personal and tactical, strategic actions and contexts related to responsibilities, demands, tasks, and work. Affective includes what is experienced and felt or emotional expression. Cognitive knowledge regarding what is learned, all of these things are multidimensional constructs of skills (Chell, 2013). Cell lists four categories of entrepreneurial skills which include traits/behaviors, managerial/leadership skills, utilizing ideas, and idea identification/creation (Shabbir et al., 2016). So, this study will examine the effect of entrepreneurial potential on intention through gender.

\section{RESEARCH METHODS}

\section{Materials}

The population in this study is the Sebelas Maret university students, Faculty of Mathematics and Natural Sciences (FMNS) class 2017, with a total of 402 students. The sample used to obtain data is 200 students. Samples were taken using probability sampling or random sampling, the type used was proportionate stratified random sampling. The research 
instrument was made using a Likert scale with 4 values, then tested the reliability and validity of the instrument

Pearson product-moment correlations the formula used to test the validity of the instrument, the criteria used to determine whether the instrument is valid or invalid is if the table has a significance level of 5\% then the instrument is valid, and if $r_{x y}<\mathrm{r}$ table then the instrument is invalid. SPSS version 20 device is a test tool used for the calculation of the validity test. Reliability test is used to test the instrument is quite reliable, with the Cronbach alpha calculation formula is good $(\alpha)$. The reliability of a variable construct is called good when the Cronbach Alpha value is $>0.70$, and vice versa if the variable has a value $<0.70$ then the variable is said to be unreliable (Cronbach, 1951). The validity and reliability tests that have been carried out show that all statement items in the research instrument are valid and reliable.

\section{Hypothesis Building}

The results of empirical observations show If perceived behavioral control and attitude change is a significant and not negative effect on one's entrepreneurial potential and intentions. This result is not the same as subjective norms so that increasing entrepreneurial potential can be done by placing the younger generation in pedagogical situations that can develop their competencies and skills in entrepreneurial activities, as well as planning to focus on increasing the knowledge base they must possess (Elina et al., 2015). Perceived worthiness and desirability, propensity to act can be said to be an effect on entrepreneurial intention (Agu \& Nwachukwu, 2020).

The results showed personality traits (risk-taking, self-efficacy, and optimism) affect entrepreneurial intention. Risk-taking is a negative influence, while self-efficacy and optimism do not is a negative impact on intentions (Abou et al., 2020). Educational perception and the ability to take risks are not significant influences on entrepreneurial intention (Madhavika, 2019). The establishment of entrepreneurial intentions can be influenced by personality traits that tend to apply indirectly that affect perceived control and attitudes (Ahmed et al., 2020). Entrepreneurial skills have no negative effect on intentions (Gieure et al., 2019). Perceived behavioral control is the main thing in measuring entrepreneurial intention. Research findings show that entrepreneurial potential does not negatively affect one's entrepreneurial intentions (Santos et al., 2013).

\section{$\mathrm{H}_{1}$ : Entrepreneurial potential affects the intention}

The relationship of potential and entrepreneurial intention would be moderated by gender, with looking at the two important components of entrepreneurial potential used in this study, namely personality traits and entrepreneurial skills. The personality approach needs to be studied to understand gender inequality in entrepreneurial intentions. Research has found that females tend to have different intentions and personalities. Finding evidence that if based on gender, the relationship between personality and entrepreneurial intentions has diversity. This will cause the emergence of an impetus for most female to expand their fields and establish their businesses (Zisser et al., 2019). Females who feel and have skills will be more likely to dare to take risks, then it will significantly affect entrepreneurial intention (Ward et al., 2019).

$\mathrm{H}_{2}$ : Gender is a moderator of the relationship of entrepreneurial potential on the intention 


\section{RESEARCH METHODS}

The analysis method in the research is carried out using the Hierarchical Multiple Regression Analysis regression equations, which serve to test directly all the variables to be tested, whether it is the main independent variable and the moderator/interaction impact of independent on the dependent variable. This data analysis was made using two equations, first, the main independent variable (entrepreneurial potential) is entered into regression equation 1. Finally, the gender variable is added to the regression equation 2.

Hierarchical Multiple Regression Analysis is one part of linear regression, so it is necessary to test the prerequisites that must be met before testing the hypothesis. The prerequisite tests include:

1. The multicollinearity test is measured by taking into account the criteria for the VIF and tolerance value, which covers: If the VIF amount 10 or tolerance value 0.10 indicates the presence of multicollinearity. When the VIF amount is 10 or the tolerance value is 0.10 , it shows that multicollinearity does not occur (Ghozali, 2013).

2. The heteroscedasticity test of this study used the graph method and the Glejser test statistic. The statistical method of the Glejser test is to absolute the residual value of the other independent variables, if the significant value is $>0.01$ then there is no heteroscedasticity. The graphical method is to see the pattern of the dots on the regression graph.

3. Residual normality, the test method used is the Kolmogorov Smirnov One-Sample Test. Decision-making is based on probability (Asymptotic Significance), including data defined normally distributed when probability $>0.05$, and the data can be said to be not normally distributed if the probability (Santoso, 2012).

Next, test the hypothesis by looking at the results of the F and t-tests. The F test serves to find out the dependent variable that is significantly influenced and jointly by the independent. The criteria for hypothesis testing use the following F test (Priyatno, 2014): The significance used is 5\% (0.05) with a 95\% confidence level and $(\mathrm{DK})=\mathrm{n}-\mathrm{k}-1$. Decisionmaking criteria: $\mathrm{F}$ table $>$ count, or when the significance value $>0.05$ then the dependent is affected by the independent variables together. When $\mathrm{F}$ table < count, or if the probability value $<0.05$ then the independent and dependent variables affect together.

This t-test is used to obtain information if the independent on the regression model impacts the dependent partially. The significant level in this study is $5 \%$, meaning that the error in making decisions is 5\%. The hypothesis to be tested is (Priyatno, 2014):

1. Ho: $\beta_{1}=0$, has meaning if the dependent is not significantly affected by the independent variable.

2. $\mathrm{H}_{0}: \beta_{1} \neq 0$, explain if the independent variable has a significant influence on the dependent.

The conclusion of this hypothesis is taken based on the results of comparing $t$ count with $t$ table or significant value: when the significant value is $<0.05$ or $t$ table $<$ count will make the dependent affected by the independent variable individual. The significant value $>0.05$ or when $t$ table > count will make the independent variable not affect the dependent variable individually. 


\section{RESULTS AND DISCUSSION}

\section{Results}

The results of the multicollinearity test for gender variables, and entrepreneurial potential have the same VIF and tolerance values, which are 1.00 and 0.10 (look at table 1), this value indicates if multikolinearitas has not happened.

Table 1. Multicollinearity test

\begin{tabular}{|l|c|c|c|c|}
\hline \multirow{2}{*}{ Model } & \multirow{2}{*}{$\mathbf{t}$} & \multirow{2}{*}{ Sig. } & \multicolumn{2}{c|}{ Collinearity Statistics } \\
\cline { 4 - 5 } & & & Tolerance & VIF \\
\hline Gender & 1.38 & 0.00 & 0.10 & 1.00 \\
\hline Entrepreneurial Potential & 13.47 & 0.17 & 0.10 & 1.00 \\
\hline
\end{tabular}

The heteroscedasticity test can be seen in table 2, decision making is taken from the value of sig. all of which are bigger than 0.01 means that heteroscedasticity does not occur.

Table 2. Heteroscedasticity test

\begin{tabular}{|l|c|c|c|c|}
\hline \multicolumn{1}{|c|}{ Model } & $\boldsymbol{\beta}$ & SE & t & Sig. \\
\hline (Constant) & 1.42 & 0.61 & 2.34 & 0.02 \\
\hline Gender & 0.00 & 0.02 & 0.05 & 0.97 \\
\hline Entrepreneurial Potential & 0.34 & 0.20 & 1.70 & 0.09 \\
\hline
\end{tabular}

The normality test shows a value of 0.200 which means that the data is normally distributed, all conditions have been met so that the analysis in this study can be continued. The results of hypothesis testing can look at in the following table provided:

Tabel 3. Results of Regression Analysis Techniques

\begin{tabular}{|c|c|c|c|c|c|c|c|c|}
\hline Dependent Variable & \multicolumn{8}{|c|}{ Intention } \\
\hline \multirow{2}{*}{ Independent Variable } & \multicolumn{4}{|c|}{ Equation 1} & \multicolumn{4}{|c|}{ Equation 2} \\
\hline & $\boldsymbol{\beta}$ & SE & $\mathbf{t}$ & Sig. & $\boldsymbol{\beta}$ & SE & $\mathbf{t}$ & Sig. \\
\hline Constant & 7.30 & 0.97 & 7.51 & 0.00 & 6.87 & 6,92 & 6.76 & 0.00 \\
\hline Entrepreneurial Potential $\left(\mathrm{H}_{1}\right)$ & 0.43 & 0.32 & 13.38 & 0.00 & 0.43 & 0.03 & 13.47 & 0.00 \\
\hline Gender $\left(\mathrm{H}_{2}\right)$ & & & & & 0.47 & 0.34 & 1.38 & 0.17 \\
\hline $\mathrm{F}$ & \multicolumn{3}{|c|}{178.91} & 0.00 & \multicolumn{3}{|c|}{90.81} & 0.00 \\
\hline R-Squ. & \multicolumn{4}{|c|}{0.48} & \multicolumn{4}{|c|}{0.48} \\
\hline Adjusted R Squ. & \multicolumn{4}{|c|}{0.47} & \multicolumn{4}{|c|}{0.47} \\
\hline
\end{tabular}

Hypothesis 1 which is assumed is Entrepreneurial potential has an effect on intention. Pay attention to table 3 which shows if entrepreneurial potential significantly influences student intentions $(\beta=0.43 ; \mathrm{F}=178.91$, sig. $<0.05 ; \mathrm{t}=13.38$, sig. $=0.00)$. Hypothesis 2 assumes that the relationship on entrepreneurial potential and intention, moderated by gender. The results in table 3 show that gender does not significantly moderate the relationship on entrepreneurial potential and student intention $(\beta=0.47 ; \mathrm{F}=90.81$, sig. $<$ $0.05 ; \mathrm{t}=1.38$, sig. $=0.17$ )

\section{Discussion}

Entrepreneurial potential leads to psychology (personality traits) and cognition (entrepreneurial skills) towards a person's entrepreneurial intention. Personality traits refer to one's risk-taking, while entrepreneurial skills refer to idea identification/creation and managerial/leadership skills. Through entrepreneurship training, a person's personality traits are no negative and significant influence on entrepreneurial intentions (Irawan et al., 2020). Entrepreneurial skills are the main factors that determine a person's perceived control and attitudes that will determine one's entrepreneurial intentions (Vega-Gómez et al., 2020). The 
entrepreneurial potential has a not negative influence on one's entrepreneurial intentions (Santos et al., 2013).

Statistical calculations show that male and female students have no differences regarding their views on entrepreneurial intentions and business competence (Kakkonen, 2011). Increasing entrepreneurial potential in educational programs can be done by focusing on increasing perceived competencies, skills, and entrepreneurial attitudes in conducting entrepreneurial activities. When entrepreneurial potential increases, the intention will also increase, so that entrepreneurial potential can be measured properly through intention (Elina et al., 2015). Human capital which includes skills, knowledge, finance, and cooperation to run a business is something that can shape one's entrepreneurial potential (Pauli \& Osowska, 2019).

\section{CONCLUSION}

This research only analyzes the impact of entrepreneurial potential on intention in terms of gender as a moderator in the relationship. We need to study more deeply the psychological characteristics that build and encourage entrepreneurial intention. We can re-examine the related entrepreneurial skills and personality traits in influencing the entrepreneurial intention of students. It is also necessary to analyze the collaboration of human capital includes of skills, knowledge, cooperation, and finances that shape entrepreneurial potential in establishing a business towards intentions.

\section{REFERENCES}

Abou, E. A. E. E., Hanafi, M., \& Ali, I. E. O. (2020). Entrepreneurial intentions: The influence of organizational and individual factors. Journal of Business Venturing, 03(1), 08-13. https://doi.org/10.1016/j.jbusvent.2009.04.003

Agu, A. G., \& Nwachukwu, A. N. (2020). Exploring the relevance of Igbo Traditional Business School in the development of entrepreneurial potential and intention in Nigeria. Small Enterprise Research. https://doi.org/10.1080/13215906.2020.1752789

Ahmed, T., Chandran, V. G. R., Klobas, J. E., Liñán, F., \& Kokkalis, P. (2020). Entrepreneurship education programmes: How learning, inspiration, and resources affect intentions for new venture creation in a developing economy. International Journal of Management Education. https://doi.org/10.1016/j.ijme.2019.100327

Bastian, B. L., Metcalfe, B. D., \& Zali, M. R. (2019). Gender inequality: Entrepreneurship development in the MENA region. Sustainability (Switzerland), 11(22). https://doi.org/10.3390/su11226472

Chell, E. (2013). Review of skill and the entrepreneurial process. International Journal of Entrepreneurial Behaviour \& Research, 19(1), 6-31. https://doi.org/10.1108/13552551311299233

Cronbach, L. J. (1951). Coefficient alpha and the internal structure of tests. Psychometrika, 16(3), 297-334. https://doi.org/10.1007/BF02310555

Dilli, S., \& Westerhuis, G. (2018). How institutions and gender differences in education shape entrepreneurial activity: a cross-national perspective. Small Business Economics, 51(2), 371-392. https://doi.org/10.1007/s11187-018-0004-x

Elina, V., Joensuu, S., Tornikoski, E., \& Viljamaa, A. (2015). The development of entrepreneurial potential among higher education students. The Eletronic Library, 22(3), 563-589.

Ghozali, I. (2013). Aplikasi Analisis Multivariate dengan Program IBM SPSS 21 Update PLS Regresi. Penerbit Universitas Diponegoro.

Gieure, C., Benavides-Espinosa, M. del M., \& Roig-Dobón, S. (2019). Entrepreneurial 
intentions in an international university environment. International Journal of Entrepreneurial Behaviour and Research, 25(8), 1605-1620. https://doi.org/10.1108/IJEBR-12-2018-0810

Gupta, V. K., Goktan, A. B., \& Gunay, G. (2014). Gender differences in evaluation of new business opportunity: A stereotype threat perspective. Journal of Business Venturing, 29(2), 273-288. https://doi.org/10.1016/j.jbusvent.2013.02.002

Hatthakijphong, P., \& Ting, H. I. (2019). Prioritizing successful entrepreneurial skills: An emphasis on the perspectives of entrepreneurs versus aspiring entrepreneurs. Thinking Skills and Creativity, 34(June), 100603. https://doi.org/10.1016/j.tsc.2019.100603

Irawan, D. A., Syakur, A. Q. A., \& Maududi, H. (2020). Entrepreneurial Intention of Indonesian Migrant Workers. December 2019.

Kakkonen, M. L. (2011). Students' Perceptions of Their Business Competences and Entrepreneurial Intention. Management, 6(3), 225-243.

Karabulut, A. T. (2016). Personality Traits on Entrepreneurial Intention. Procedia - Social and Behavioral Sciences, 229, 12-21. https://doi.org/10.1016/j.sbspro.2016.07.109

Kristiansen, S., \& Indarti, N. (2004). Entrepreneurial Intention Among Indonesian and Norwegian Students. Journal of Enterprising Culture, 12(01), 55-78.

Krueger, N. F., \& Brazeal, D. V. (1994). Entrepreneurial Potential and Potential Entrepreneurs. Entrepreneurship Theory and Practice. https://doi.org/10.1177/104225879401800307

Madhavika, W. D. N. (2019). Entrepreneurial Intentions of Sri Lankan Undergraduates. International Journal of Academic Research in Business and Social Sciences, 9(6). https://doi.org/10.6007/ijarbss/v9-i6/5935

Mamman, A., Olaoye, I. K., Abdulrahaman, A. M., Shagari, J. N., \& Lekan, O. K. (2019). The Influence of Entrepreneurship Education on the Entrepreneurial Intentions of University Students in Katsina State, Nigeria. Acta Universitatis Sapientiae, Economics, and Business, 6(1), 21-42. https://doi.org/10.1515/auseb-2018-0002

Mubarik, M. S., Mujahid, S., \& Naghavi, N. (2020). Developing entrepreneurial intentions: what matters. Middle-East J. of Management, $7(1), 41$. https://doi.org/10.1504/mejm.2020.10026906

Pauli, U., \& Osowska, R. (2019). Building entrepreneurial potential abroad - exploring return migrant experience. International Journal of Entrepreneurial Behaviour and Research, 25(5), 936-954. https://doi.org/10.1108/IJEBR-02-2018-0098

Priyatno, D. (2014). SPSS 22 Pengolahan Data Terpraktis. CV Andi Offset.

Qian, C., Li, F., Antonides, G., Heerink, N., Ma, X., \& Li, X. (2020). Effect of personality traits on smallholders' land renting behavior: Theory and evidence from the North China $\begin{array}{llll}\text { Plain. China Economic Review, } & \text { 62(July), }\end{array}$ https://doi.org/10.1016/j.chieco.2020.101510

Santos, S. C., Caetano, A., \& Curral, L. (2013). Psychosocial aspects of entrepreneurial potential. Journal of Small Business and Entrepreneurship. https://doi.org/10.1080/08276331.2014.892313

Santoso, S. (2012). Statistik Parametik. PT Gramedia Pustaka Umum.

Sargani, G. R., Zhou, D., Mangan, T., \& Rajper, H. (2019). Determinants Of Personality Traits Influence On Entrepreneurial Intentions Among Agricultural Students Evidence From Two Different Economies. European Journal of Business and Management Research, 4(5). https://doi.org/10.24018/ejbmr.2019.4.5.105

Shabbir, M. S., Shariff, M. N. M., \& Shahzad, A. (2016). A Conceptual Development of Entrepreneurial Skills and Entrepreneurial Intentions: A Case of IT employees in Pakistan. International Journal of Academic Research in Business and Social Sciences, 
6(3). https://doi.org/10.6007/ijarbss/v6-i3/2040

Syed, I., Butler, J. C., Smith, R. M., \& Cao, X. (2020). From entrepreneurial passion to entrepreneurial intentions: The role of entrepreneurial passion, innovativeness, and curiosity in driving entrepreneurial intentions. Personality and Individual Differences. https://doi.org/10.1016/j.paid.2019.109758

Tambunan, F. (2021). The Effect of Business Planning and Record on Entrepreneur Success. Randwick International of Social Science Journal, 2(3), 236-240. https://doi.org/10.47175/rissj.v2i3.261

Thompson, E. R. (2009). Entrepreneurial Intent: and Development Reliable Metric. Entrepreneurship: Theory and Practice, 33(0), 669-695. http://papers.ssrn.com/sol3/papers.cfm?abstract_id=1396451

Vega-Gómez, F. I., Miranda González, F. J., Chamorro Mera, A., \& Pérez-Mayo, J. (2020). Antecedents of Entrepreneurial Skills and Their Influence on the Entrepreneurial Intention of Academics. SAGE Open, 10(2). https://doi.org/10.1177/2158244020927411

Vodă, A. I., \& Florea, N. (2019). Impact of personality traits and entrepreneurship education on entrepreneurial intentions of business and engineering students. In Sustainability (Switzerland) (Vol. 11, Issue 4). https://doi.org/10.3390/SU11041192

Ward, A., Hernández-Sánchez, B. R., \& Sánchez-García, J. C. (2019a). Entrepreneurial Potential and Gender Effects: The Role of Personality Traits in University Students' Entrepreneurial Intentions. Frontiers in Psychology. https://doi.org/10.3389/fpsyg.2019.02700

Zisser, M. R., Johnson, S. L., Freeman, M. A., \& Staudenmaier, P. J. (2019). The relationship between entrepreneurial intent, gender, and personality. Gender in Management. https://doi.org/10.1108/GM-08-2018-0105 